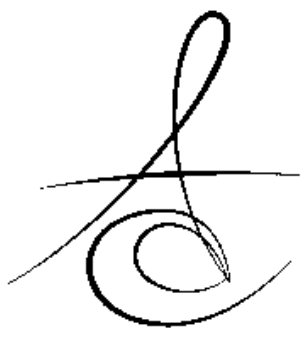

Makale Kodu/Article code: 2578

Makale Gönderilme tarihi: 01.02.2016

Kabul Tarihi: 23.03.2016

\section{DOUBLE-LOBED MAXILLARY SINUS LIFT AND DENTAL IMPLANT TREATMENT: A CASE REPORT ${ }^{*}$}

\author{
ÇİFT LOBLU MAKSİLLER SİNÜS LİFTİNG VE DENTAL İMPLANT \\ UYGULAMASI: BİR OLGU SUNUMU ${ }^{*}$
}

Yrd. Doç. Dr. Fatih KARAASLAN*

\section{ABSTRACT}

Maxillary sinus lifting is one of the most common surgical procedures in the case of inadequate maxillary posterior vertical bone. Maxillary sinus septa can complicate inversion of lateral window and elevation of sinus membrane during the sinus lift surgery. The aim of this case report was to perform correct steps of sinus lift surgery and dental implant application in the presence of maxillary sinus septa.

48 year-old-female patient was admitted to our clinic for implant treatment at left maxillary region. In the radiographic examination, insufficient vertical bone height and double-lobed maxillary sinus were seen. Maxillary sinus lifting procedure was performed separately for both lobes. Formation of sufficient vertical bone height was lasted about 6 months for dental implant application. After this period, dental implant was performed and osseointegration has occurred.

Maxillary sinus lifting procedure is a predictable technique to increase bone volume of posterior maxilla and for dental implant placement in the presence of anatomical variations.

In the posterior maxilla, anatomical variations like sinus septa should be well known by the surgeon to prevent possible complications during sinus lifting.

Key words: dental implant, sinus lifting, osseointegration

\section{öz}

Sinüs lifting operasyonu maksiller posterior bölgede yetersiz vertikal kemik varlığında uygulanan en yaygın cerrahi operasyon tekniğidir. Sinüs septa varlığı, sinüs lifting operasyonu sırasında lateral pencerenin açılması ve sinüs membran elevasyonunda komplikasyonların oluşmasına neden olabilmektedir. Bu olgu sunumunun amacı septa varlığında sinüs lifting oprasyonun tüm basamaklarının doğru bir şekilde yapılması ve dental implant uygulamasının başarılı olmasıdır.

48 yaşındaki bayan hasta kliniğimize sağ üst çene bölgesine implant tedavisi görmek için başvurdu. Radyografik muayenede ilgili bölgede azalmış kemik yüksekliği ve çift loblu maksiller sinüs varlığı gözlendi. Her iki maksiller loba ayrı ayrı sinüs lifting işlemi yapıldı. Sinüs lifting işleminden altı ay sonra yeterli kemik yüksekliği sağlandıktan sonra dental implantlar yerleştirildi. Dental implantların 3 ay sonra yapılan kontrollerinde osseointegrasyonun sağlandığı gözlemlendi.

Sinüs lifting operasyonu anatomik varyasyonların varlığında da posterior maksiller kemiğin vertikal yüksekliğin arttırımasında ve implant uygulamasında kullanılabilir bir yöntemdir.

Posterior maksiller bölgede sinüs septa gibi anatomik varyasyonların sinüs lifting operayonu sırasında oluşabilecek komplikasyonları önlemek için cerrah tarafından çok iyi bir şekilde bilinmesi gerekmektedir.

Anahtar Kelimeler: diş implantları, sinüs lifting, osseointegrasyon

\footnotetext{
*Uşak Üniversitesi, Diş Hekimliği Fakültesi, Periodontoloji AD

${ }^{* *}$ Kocatepe Üniversitesi, Diş Hekimliği Fakültesi, Periodontoloji AD

${ }^{\text {* }}$ Europerio 8' de ( 3-6 Haziran 2015, London, UK) poster olarak sunulmuştur.
} 


\section{INTRODUCTION}

Dental implants for the treatment of missing teeth has became a commonly used method at the present time. ${ }^{1}$ Bone resorption and sinus pneumatization after tooth extraction in maxillary posterior region causes reduction in vertical height of the alveolar bone. These structural changes make the region unsuited for implant application. ${ }^{2,3}$

Sinus lifting is the most common surgical procedure that provides augmentation of posterior maxilla in the case of inadequate amount of vertical bone. $^{1}$ Anatomical variations such as sinus floor convolutions, sinus septum and narrow sinus must be well know in order to achieve the success of maxillary sinus lift surgery. ${ }^{4}$

Radiographic identification of these structures is important in order to perform right design of lateral window for sinus lifting. Aim of this investigation is to highlight the correct sinus lift surgery and dental implant application in presence of maxillar sinus septa. ${ }^{5}$

\section{CASE PRESENTATION}

48 year-old-female patient was admitted to our clinic for implant treatment at left maxillary region. In the radiographic examination, insufficient vertical bone height and double-lobed maxillary sinus were seen.

Maxillary sinus lifting procedure was performed under local anesthesia. An incision was made a few millimeters above the muco-gingival junction from canine eminence to zygomatic buttress.

A mucoperiosteal flap was elevated and two rectangular windows were created. The sinus membrane was dissected intact from the underlying bone and sufficient mucosa had been freed to allow tension free reflection from the sinus floor for both lobes. The graft ( Bio-Oss, Geistlich Biomaterials, Switzerland) was placed in the sinus cavity and was packed after achieving adequate elevation. A barrier membrane of collagen (Bio-Oss, Geistlich Biomaterials, Switzerland) was placed over the grafted site. The incision was closed with 4-0 silk suture.

Amoxicillin 625 mg, metronidazole 500 mg, $550 \mathrm{mg}$ naproksen sodium, and a nasal decongestant was prescribed twice a day for 5 days postoperatively. The patient was advised to follow standard postoperative instructions, which included ice-pack, soft high nutrient diet, thorough rinsing with antiseptic mouthwash (chlorhexidine gluconate $0.2 \%$ ). The patient was instructed to avoid sneezing, nose blowing, or other actions that might create high intranasal pressure or vacuum.

The patient followed up post-operatively at $1^{\text {st }}$ week, $6^{\text {th }}$ week, $12^{\text {th }}$ week and $24^{\text {th }}$ week and followup for implant stability checking was done at 1 and 3 months of implant application.

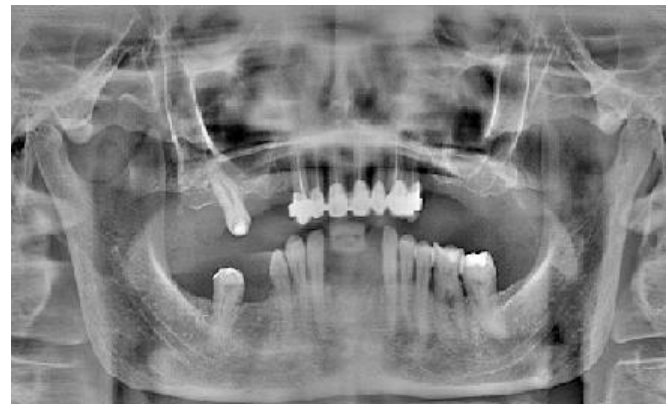

Figure 1. Pre-operative radiography

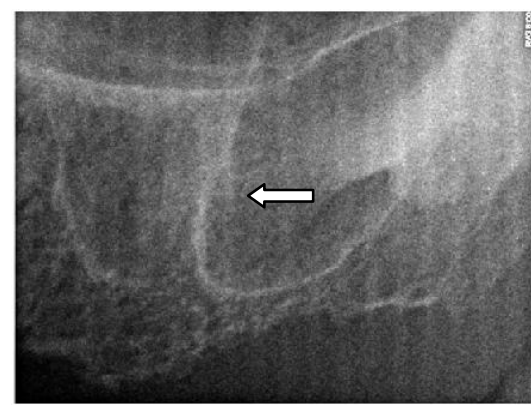

Figure 2. Pre-operative radiography of sinus maxillaris and sinus septa. Sinus septa is shown with

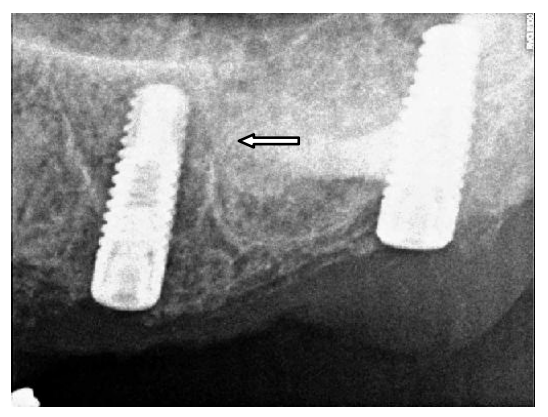

Figure 3. Radiograpy after sinus lifting and dental implant application. Sinus septa is shown with 'ڤ'

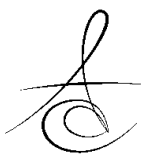




\section{DISCUSSION}

The walls of cortical bone that divide the maxillary sinus floor named maxillary sinus septa and that was first described in 1910 by Underwood. ${ }^{2}$ The prevalence of maxillary sinus septa vary between $13 \%-35 \%{ }^{2,6,7}$ and that can allocate maxillary sinus into two or more components. Sinus septa has been considered clinically insignificant variation for decades but it has gained practical relevance and must be well known to be successful in implant dentistry. ${ }^{8}$

Septa is an important restrictive feature for implant application that may complicate creation and inversion of the access window in the lateral sinus wall and increases the risk of sinus membrane perforation. ${ }^{9,10}$ Boyne et al. advises cutting the septa with a chisel and remove them with hemostatic forceps, so that graft can be placed without interruption. ${ }^{1}$ Sometimes, it is necessary to modify the lateral window design to avoid fracturing the septa: if septa is high ( $\geq 3 \mathrm{~mm}$ ) it is advised to make two windows, one on each side or make one $w$-shaped window if septa is lower $(\leq 3 \mathrm{~mm})^{11,12}$ In this case report, two adjacent windows instead of one was performed to facilitate access to and elevation of the Schneiderian membrane. In our opinion septa might be formed as a buttress to retain the volume and form of the maxillary sinus. Removing the septa can cause membrane perforation and damage this maxillary sinus harmony.

Sinus septa can be divided into primary and secondary septa. Primary septa arise from the development of the maxilla whereas secondary septa arise from the irregular pneumatization of the sinus floor following tooth loss. ${ }^{13}$ The septa in edentulous ridge cannot be distinguished into primary or secondary septa without previous radiography. Therefore, septa above an edentulous ridge like our case can be called primary or secondary.

Surgical operations in the posterior region of maxilla require detailed knowledge of maxillary sinus anatomy and variations. Diagnosis of the maxillary sinus septa is essential to avoid from complications during sinus lifting.

\section{REFERENCES}

1. Boyne PJ, James RA. Grafting of the maxillary sinus floor with autogenous marrow and bone. J Oral Surg 1980; 38: 613-6.

2. Underwood AS. An Inquiry into the Anatomy and Pathology of the Maxillary Sinus. J Anat Physiol
1910; 44: 354-69.

3. Lee WJ, Lee SJ, Kim HS. Analysis of location and prevalence of maxillary sinus septa. J Periodontal Implant Sci, 2010; 40: 56-60.

4. Chanavaz M. Maxillary sinus: anatomy, physiology, surgery, and bone grafting related to implantologyeleven years of surgical experience (1979-1990). J Oral Implantol, 1990; 16: 199-209.

5. Beretta M, Cicciu M, Bramanti E, Maiorana C. Schneider membrane elevation in presence of sinus septa: anatomic features and surgical management. Int J Dent, 2012; 2012: 261905.

6. Krennmair G, Ulm C, Lugmayr H. Maxillary sinus septa: incidence, morphology and clinical implications. J Craniomaxillofac Surg 1997; 25: 261-5.

7. Shibli JA, Faveri M, Ferrari DS, Melo L, Garcia RV, d'Avila S, Figueiredo LC, Feres M. Prevalence of maxillary sinus septa in 1024 subjects with edentulous upper jaws: a retrospective study. J Oral Implantol 2007; 33: 293-6.

8. Rysz M, Bakon L. Maxillary sinus anatomy variation and nasal cavity width: structural computed tomography imaging. Folia Morphol (Warsz), 2009; 68: 260-4.

9. Betts NJ, Miloro M. Modification of the sinus lift procedure for septa in the maxillary antrum. J Oral Maxillofac Surg, 1994, 52: 332-3.

10. van den Bergh JP, ten Bruggenkate CM, Disch FJ, Tuinzing DB. Anatomical aspects of sinus floor elevations.Clin Oral Implants Res 2000;11: 256-65.

11. Tidwell JK, Blijdorp PA, Stoelinga PJ, Brouns JB, Hinderks $F$. Composite grafting of the maxillary sinus for placement of endosteal implants. A preliminary report of 48 patients. Int J Oral Maxillofac Surg, 1992, 21: 204-9.

12. Garg AK. Bone biology, harvesting, grafting for dental implants rationale and clinical applications. 1th edition. Illionis: Quintessence Publishing Co, Inc.; 2004, 171-211

13. Krennmair G, Ulm CW, Lugmayr $H$, Solar P. The incidence, location, and height of maxillary sinus septa in the edentulous and dentate maxilla. J Oral Maxillofac Surg 1999; 57: 667-71

\author{
Yazışma Adresi \\ Yrd. Doç. Dr. Fatih KARAASLAN \\ Uşak Üniv. Diş Hek Fak. Periodontoloji AD. \\ Uşak \\ TIf: 02762215861 \\ e-mail: fatih.karaaslan@usak.edu.tr
}

